\title{
Microalgal Production of Biofuels Integrated with Wastewater Treatment
}

\author{
Merrylin Jayaseelan ${ }^{1}\left(\mathbb{D}\right.$, Mohamed Usman ${ }^{2}$, Adishkumar Somanathan ${ }^{3}$, Sivashanmugam Palani ${ }^{4}$, \\ Gunasekaran Muniappan ${ }^{5}$ and Rajesh Banu Jeyakumar ${ }^{6, *}$ (1)
}

1 Department of Food Science and Nutrition, Sarah Tucker College, Tirunelveli 627007, Tamil Nadu, India; merrylin_86@yahoo.co.in

2 Department of Civil Engineering, PET Engineering College, Vallioor 627117, Tamil Nadu, India; mdus@live.in

3 Department of Civil Engineering, Anna University Regional Campus, Tirunelveli 600025, Tamil Nadu, India; adishk2002@yahoo.co.in

4 Department of Chemical Engineering, National Institute of Technology,

Tiruchirappalli 110040, Tamil Nadu, India; psiva@nitt.edu

5 Department of Physics, Anna University Regional Campus, Tirunelveli 600025, Tamil Nadu, India; mgunat75@gmail.com

6 Department of Life Sciences, Central University of Tamil Nadu, Thiruvarur 610001, Tamil Nadu, India

* Correspondence: rajeshces@gmail.com

Citation: Jayaseelan, M.; Usman, M.; Somanathan, A.; Palani, S.;

Muniappan, G.; Jeyakumar, R.B. Microalgal Production of Biofuels Integrated with Wastewater Treatment. Sustainability 2021, 13 8797. https://doi.org/10.3390/ su13168797

Academic Editor: Alessio Siciliano

Received: 14 June 2021

Accepted: 20 July 2021

Published: 6 August 2021

Publisher's Note: MDPI stays neutral with regard to jurisdictional claims in published maps and institutional affiliations.

Copyright: (c) 2021 by the authors. Licensee MDPI, Basel, Switzerland. This article is an open access article distributed under the terms and conditions of the Creative Commons Attribution (CC BY) license (https:/ / creativecommons.org/licenses/by/ $4.0 /)$.
Abstract: Human civilization will need to reduce its impacts on air and water quality and reduce its use of fossil fuels in order to advance towards a more sustainable future. Using microalgae to treat wastewater as well as simultaneously produce biofuels is one of the approaches for a sustainable future. The manufacture of biofuels from microalgae is one of the next-generation biofuel solutions that has recently received a lot of interest, as it can remove nutrients from the wastewater whilst capturing carbon dioxide from the atmosphere. The resulting biomass are employed to generate biofuels, which can run fuel cell vehicles of zero emission, power combustion engines and power plants. By cultivating microalgae in wastewater, eutrophication can be prevented, thereby enhancing the quality of the effluent. Thus, by combining wastewater treatment and biofuel production, the cost of the biofuels, as well as the environmental hazards, can be minimized, as there is a supply of free and already available nutrients and water. In this article, the steps involved to generate the various biofuels through microalgae are detailed.

Keywords: microalgae; wastewater treatment; biofuel; nutrient removal

\section{Introduction}

From sea ice in the Arctic to microbiotic crusts in deserts, the term "algae" refers to a wide group of (mainly) autotrophic, aquatic creatures found all over the world [1,2]. Algae are usually one of two types such as macro and micro algae. Macroalgae are generally considered terrestrial plants that returned to a damp environment, according to evolutionary theory. They are classified into red, brown, and green algae and are diverse forms of multicellular eukaryotes, each with a respective evolution pathway. They have leaves and branches and may be fixed firmly [3]. Microalgae, on the other hand, are unicellular and range in size from nanometers to millimetres. Microalgae is defined by phycologists as a creature with chlorophyll and a body (thallus) that is not divided into roots, leaves (thallophytes), and stems [4]. They comprise both the prokaryotes and eukaryotes. Microalgae fix carbon dioxide more efficiently than terrestrial plants, and are widely known for capturing both atmospheric and industrial pollutants [5].

According to the research conducted earlier, production of algae biomass are 5-10 times higher than terrestrial plants, indicating a considerable chance of increased biomass production [6]. Microalgae are considered as the most successful feedstock for biodiesel synthesis due to their high photosynthetic activity, effective capture of the emitted carbon dioxide, 
and remarkable environmental adaptation, including high algal production [7-9]. Thus, algae utilize carbon dioxide, along with sunlight and water, to produce sugars through photosynthesis. The products thus obtained are broken down into carbohydrates, proteins, lipids, nucleic acids, etc. The fatty acid content varies with each type of algae. Fatty acids can account for up to $40-50 \%$ of the entire mass of some algae species. Table 1 details the general composition of various microalgae.

Table 1. General composition of various microalgae on percentage dry matter basis [10].

\begin{tabular}{cccc}
\hline Microalgae Species & Protein & Carbohydrates & Fatty Acids \\
\hline Anabaena cylindrica & $43-56$ & $25-30$ & $4-7$ \\
\hline Aphanizomenonflos-aquae & 62 & 23 & 3 \\
\hline Chlamydomonas rheinhardii & 48 & 17 & 21 \\
\hline Chlorella pyrenoidosa & 57 & 26 & $14-22$ \\
\hline Chlorella vulgaris & $51-58$ & $12-17$ & 6 \\
\hline Dunaliella salina & 57 & 32 & $14-20$ \\
\hline Euglena gracilis & $39-61$ & $14-18$ & $9-14$ \\
\hline Porphyridiumcruentum & $28-39$ & $40-57$ & $12-14$ \\
\hline Scenedesmus obliquus & $50-56$ & $10-17$ & $11-21$ \\
\hline Spirogyra sp. & $6-20$ & $33-64$ & $6-7$ \\
\hline Arthrospira maxima & $60-71$ & $13-16$ & $4-9$ \\
\hline Spirulina platensis & $46-63$ & $8-14$ & 11 \\
\hline Synechococcus sp. & 63 & 15 &
\end{tabular}

Current biofuel production from microalgal biomass is limited by a lack of dependable and cost-effective technologies for producing and harvesting algal feedstocks [11]. Muchrecent research has proposed that algal biomass production be combined with wastewater treatment and recycling to equalize the expense of fertilisers and freshwater necessary for microalgae growing [12-15]. This combination of algal biomass generation and wastewater treatment also helps to purify wastewater [16-18]. Microalgal cells' nutrient absorption ability can lower the nitrogen and phosphorus content of wastewater to a relatively low level, allowing it to fulfil the increasingly stricter nutrient discharge standards [19,20]. Most nutrients in the wastewater are eliminated, suggesting the possibility of integrating wastewater treatment with algal biomass production. In addition, the nutrients in the wastewater are not only eliminated from the wastewater, but they are also caught by the microalgae and returned to the environment as agricultural fertilisers. Another benefit of microalgae-based wastewater treatment is that the algal cells fix the greenhouse gas (carbon dioxide) through photosynthesis. Microalgae cultivations have been widely employed for wastewater treatment so far, demonstrating the capacity to remove nutrients from a variety of wastewater types, including wastewater from industries [21,22], municipal wastewater [23,24], cattle wastewater [14,25], and aquaculture wastewater [18]. Microalgae may utilize the nutrients in wastewater to flourish, and the wastewater may be treated at the same time. Large amounts of freshwater and nutrients necessary for algal development might be conserved by utilising wastewater. Using microalgae to remediate wastewater for biofuel production is a more sustainable and ecologically beneficial option. Algal growth is primarily reliant on carbon, nitrogen, and phosphorus. Various wastewater sources, such as urban wastewater, agricultural run-off, animal wastewaters, and industrial water, often provide adequate carbon, nitrogen, and phosphorus for algae to thrive efficiently. Algae may develop in a variety of wastewaters as long as there is enough carbon (both organic or inorganic), nitrogen (in the form of urea, ammonium, or nitrate), and other trace components [26]. Due to its efficiency and requirement, widespread production of algal 
biomass for biofuel and other purposes utilising wastewaters is attracting increased interest for study.Nutrient removal efficiency of microalga in different wastewater is tabulated in Table 2.

Table 2. Microalgal nutrient removal efficiencies from various wastewaters.

\begin{tabular}{|c|c|c|c|c|}
\hline Wastewater & Strain & $\begin{array}{l}\text { Removal of Total } \\
\text { Nitrogen }(\%)\end{array}$ & $\begin{array}{l}\text { Removal of Total } \\
\text { Phosphorus (\%) }\end{array}$ & Reference \\
\hline Municipal sewage water & Chlorella & 97.81 & 89.39 & [27] \\
\hline Pharmaceutical wastewater & Chlorella sorokiniana & 70 & 89 & [28] \\
\hline Landfill Leachate & Chlorella vulgaris & 69 & 100 & [29] \\
\hline Aquaculture wastewater & $\begin{array}{l}\text { Chlorella } \\
\text { vulgaris } \\
\text { and } \\
\text { Scenedesmus } \\
\text { obliquus }\end{array}$ & 86.1 & 82.7 & [18] \\
\hline Textile wastewater & Mixed consortia of Microalga & 95 & 70 & [30] \\
\hline Edible Oil Refinery wastewater & Desmodesmussp & 96 & 53 & [31] \\
\hline Dairy wastewater & Chlorella vulgaris & 85.47 & 65.96 & {$[32]$} \\
\hline
\end{tabular}

Algae may be harvested from the treatment facility on a regular basis and used to make biofuel. In comparison to traditional wastewater treatment technologies, simultaneous wastewater treatment and algae culture can give a more cost-effective and environmentally friendly wastewater treatment. It has been demonstrated that it is a more cost-effective method of removing biochemical oxygen demand, pathogens, phosphate, and nitrogen than activated sludge [33]. This review paper discusses the various biofuels obtained through the nutrient removal in wastewater using microalgae (as shown in Figure 1). The fuels generated are biodiesel, biomethanol, biomethane, biohydrogen, bioprocessed esters and fatty acids, and synthestic fuels such as Fischer Tropsch Diesel, Dimethyl ether, and methanol.

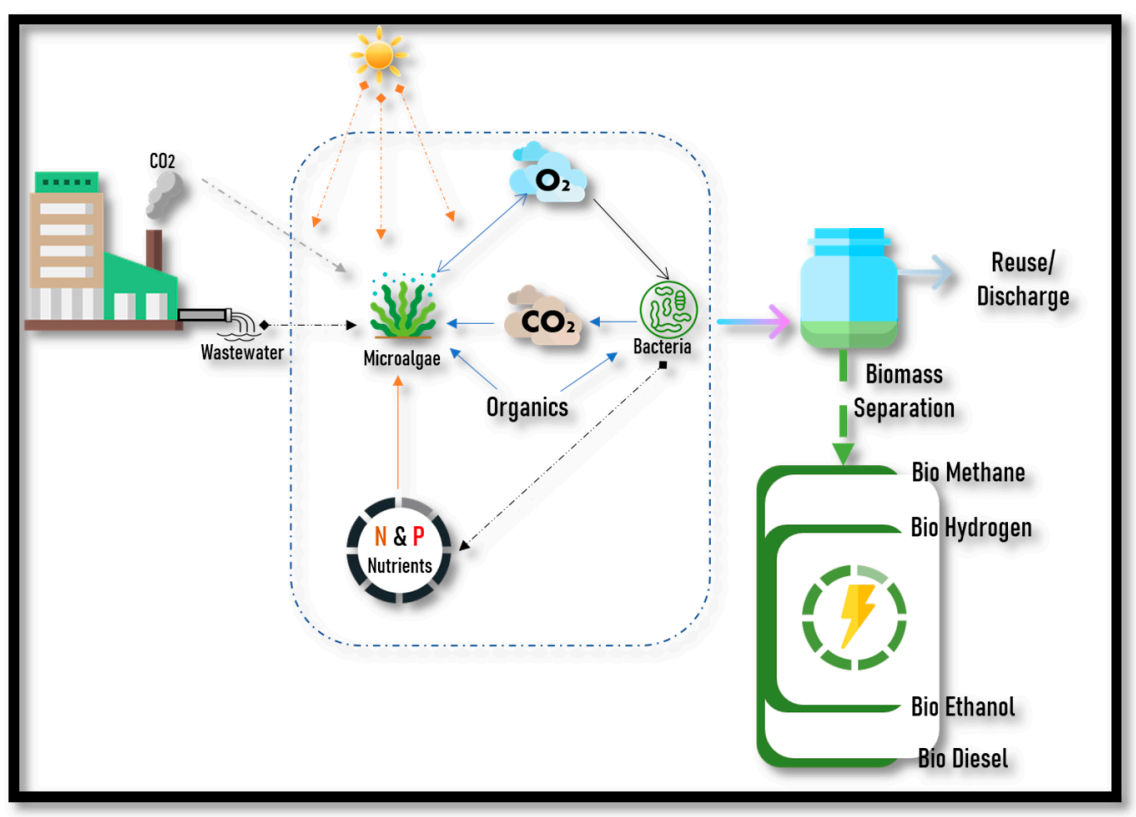

Figure 1. Microalgal wastewater treatment and the application of the produced biomass. 


\section{Biofuel Production Pathways}

Biofuels using microalgae can be produced through various pathways such as (i) physicochemical pathway, which involves transesterification or esterification,(ii) biochemical conversion, which involves alcoholic fermentation, dark fermentation, anaerobic digestion, andbiophotosynthesis, and (iii) thermochemical conversions such as pyrolysis, gasification, hydrothermal processes, or hydro-processing. Biomethane is produced by anaerobic digestion $[34,35]$, biohydrogen is generated by biophotosynthetic process [36,37], bioethanol is produced by fermentation [38,39], liquid fats by thermal liquefaction [40-43], and biodiesel by transesterification or esterification process $[40,44,45]$.

\subsection{Biodiesel}

The triglyceride transesterification technique has been used in biodiesel production for more than 50 years [46]. During transesterification, fatty acid esters are formed when the triglycerides react with alcohol, and when the reaction is sped up by a catalyst.As the chemical processes involved in the manufacture of biodiesel are rather slow, catalysts are utilised to speed them up. Biodiesel manufacturing methods can be chemical or biotechnological, depending on the kind of catalyst used in the process. Biodiesel may be made from algal biomass in a variety of ways (including oil extraction from algal biomass) via esterification and direct transesterification of microalgae [47]. Fatty acid methyl esters (FAMEs), the chemical component of biodiesel, are usually generated in algal biodiesel processes by transesterification of algal oil with the alcohol (methanol) utilizing 98\% concentrated sulfuric acid as a catalyst and n-hexane as a solvent. Extraction of oil from the microalgae without breaking their cells is a novel way in using nano catalysts for biodiesel synthesis from microalgae [48]. In situ transesterification is a promising method for avoiding oil extraction and directly converting lipids within microalgae cells to biodiesel in a single step, which might simplify biodiesel manufacturing procedures while also producing more biodiesel [49].

Generally, microalgae oil contains more free fatty acids compared to the oil from terrestrial plants; therefore, during biodiesel production from microalgae oil, free fatty acids should be esterified using acid catalysts prior to usual transesterification. In a research conducted by Ashokkumar, the fatty acids in the microalgae Botryococcus braunii were esterified using $1.5 \%$ concentrated sulphuric acid at a temperature of $55{ }^{\circ} \mathrm{C}$ for about 20 min prior to transesterification. The initial fatty acid content was $9.7 \%$ in the microalgae, and it decreased to 0.55 percent after esterification [50].

Unlike terrestrial oily plants (such as palm, soybean, or canola seed), algal oil may be recovered readily from the algal cell by compressing it, followed by solvent extraction. Mechanical crushing of algal biomass is another option, although extracting algal oil with the current technology is quite challenging. The majority of extraction methods are based on Bligh and Dryer's 1959 approach. [51]. Cold pressing is the least costly method of extraction of algal oil [47]. This method may extract up to $70 \%$ of the oil contained inside the algae [52]. The addition of an organic solvent can improve the extraction level to $99 \%$, but this comes at a cost in terms of processing [53].

When assessing the potential of different microalgal strains for biodiesel generation, it's crucial to keep in mind that all microalgal oils are not suitable for the production of biodiesel. Biodiesel made from microalgae is similar to biodiesel made from other sources, such as oleaginous plants, in that it has limited oxidative stability due to a high degree of unsaturation.

Blending biodiesel with fossil fuel and/or adding chemical stabilisers can help in improving it [54-56]. The temperature-related features of diesel, such as cloud point and cold filter plugging point, become critical in cold climates for optimal fuel performance. [57]. Other important factors to be considered are the energy content which provides the intrinsic value of the fuel, acidic, and water content in the fuel which determines its corrosive nature, and the viscosity of the fuel to determine the proficient operation of the engine [54]. 


\subsection{Biomethane}

Biogas is one of the most promising biofuels, with the ability to alleviate some of the rising worries about fossil fuels, such as the energy calamity and change in the weather [58,59]. Application of microalgae have been shown to be efficient, practical, and cost-effective in biogas generation [60-62]. Microalgae are particularly well suited for combined nutrient removal through wastewater treatment and carbon dioxide sequestration, due to their ability to assimilate large amounts of carbon dioxide and the possibility of blending microalgal cultivation with flue gas emissions or biogas upgrading, which involves removing carbondioxide (as biogas) to increase methane percentage [63-65]. Microalgae cultivation at a wastewater treatment facility offers a free source of water and nutrients, while also contributing to the wastewater treatment process and allowing the recycling of vital nutrients that would otherwise be lost to the environment. The resulting microalgal biomass can subsequently be processed to extract nutrients for fertiliser production or oils for biodiesel generation. Biogas can also be produced through anaerobic digestion of residual biomass [66-68]. Biomethane is generated via biochemical conversion of biomass, followed by gas upgrading, or by thermochemical conversion of solid biomass through gasification, followed by gas cleaning, methanation as the process of synthesis, and biogas upgrading of the product.

Anaerobic digestion by microalgae was first detailed by Golueke and his coworkers in 1957 by means of Chlorella sp. and Scenedesmus sp.,whichgenerated nearly 0.17-0.32 L $\mathrm{CH}_{4} / \mathrm{gVS}$ [69]. However, for two reasons, microalgae biomass is not currently considered a viable substrate for biogas production in the anaerobic digestion process: (i) the rigid cell wall of the microalgae confers a high level of resistance to microbial degradation, and (ii) due to the high protein content, the biomass has very low carbon-to-nitrogen $(\mathrm{C} / \mathrm{N})$ ratio, which is unfavourable $[69,70]$. Three different microalgae, belonging to the genus Scenedesmus, Chlorella, and Chlamydomonas, displayed higher carbon/nitrogen ratio in the biomass (24-26 on the basis of weight) when those microalgae were starved. Consecutively, they also lost their capacity to resist degradation by bacteria, thus leading to higher production of biomethane [71], with their conversion rates nearly equal to the theoretical threshold value [70].

By weakening or breaking the microalgae cell wall structure via pretreatment, we can improve the anaerobic biodegradability of microalgae; co-digestion also enhances the biogas yield by increasing the organic loading rate while controlling the concentration of ammonia. For a better understanding and optimization of the performance of the process, mathematical models and reactor design and operation techniques must be carefully studied. Finally, the biogas generated during the anaerobic digestion of microalgae should be improved before being burned on-site or injected into natural gas systems or utilized as liquefied petroleum gas.

To aid compression, to improve calorific value, and to avoid metal component corrosion, all hydrogen sulphide and other trace gases must be eliminated before biogas can be utilised in generators or fed to national gas networks. These steps can be through various chemical scrubbing methods [72,73]. However, the systems involved are huge and difficult to scale down, and can produce very hazardous by-products. Therefore, biotrickling and bioscrubbing have been developed as ecologically viable biological processes.

The use of the entire algal cell and the ability to employ low-quality algae sources, such as wastewater treatment or blooms, are the advantages of the biogas generation in general.

\subsection{Biohydrogen}

The term "biohydrogen" refers to hydrogen created biologically, most typically by algae, bacteria, and archaea, either through cultivating them or from organic waste sources [74]. Hydrogen is considered as yet another sustainable energy source generated by photosynthetic organisms, with a higher energy content of about $122 \mathrm{~kJ} / \mathrm{g}$, which is nearly 2.75 times greater than that of hydrocarbon fuels [75]; due to this reason, it has 
been considered a viable alternative to fossil fuels and as an carrier of energy. A number of microalgae species, such as Anabaena sp. [76], Chlorella vulgaris [77], Nannochoropsis sp. [78], Chlamydomonas reinhardtii [79], Spirulina maxima [80], and Scenedesmus obliquus [77,81], are capable of generating molecular hydrogen through the photofermentative metabolism. Among the various species, Chlorella vulgaris is the most commonly used untreated substrate for hydrogen generation. Hydrogen yield acquired from various species ranged from 0.37 to $19 \mathrm{~mL}$ of hydrogen/g VS, and highest hydrogen yield was achieved from Chlorella vulgaris [82] and the Scenedesmus sp. [83].

Microalgal hydrogen production is facilitated by the solar light, or by fermentation processes and various thermochemical techniques used to convert the biomass. Production of molecular hydrogen by microalgae is carried out in the presence of the enzyme hydrogenase, which utilizes water as the only electron donor. [84].However, as the hydrogenase enzyme that produces biohydrogen is particularly sensitive to oxygen and becomes inactive even at a partial pressure of $2 \%$ of oxygen, [85], the ability of microalgae to stimulate hydrogen production shows only after acclimatization to anaerobic environment and is vanished in the presence of even small amount of oxygen [86]. Thus, due to its incompatibility to oxygen, the ability of microalgae lasts only for a short period of time.

In 1939, Gaffron and Rubin conducted the first scientific experiment of generating hydrogen using microalgae. In their study, it was reported that Scenedesmus obliquus was able to generate hydrogen at low rates under two conditions, such as in the dark environment and by replacing the culture's atmosphere with nitrogen gas [87]. Thus, it can be stated that the production of hydrogen depends on the mechanism of algae to adapt to the transition phase during which the dark anaerobic condition is switched to oxygenic condition to perform photosynthesis. The electron transport pathway is re-oxidized only through this transition [88].

Due to the low rate of biohydrogen production, the microalgae should be pretreated to convert the complex carbohydrates into simple sugars, thereby increasing the surface area (through the disruption of cell and disintegration of the cell wall) for the action of microbes. To increase the production of biohydrogen, physical, chemical, and biological pretreatments are employed. Physical pretreatment includes mechanical, thermal, and ultrasonication. Chemical pretreatment is carried out by the addition of acid or base or by ozonation.Microbes and enzymes are used in biological pretreatment to disrupt the microalgal biomass and liberate intracellular components, thus increasing the biohydrogen production rate. Enzymes are selected based on the composition of the microalgal cell wall. Another method to increase the hydrogen yield is through metabolic engineering and screening for mutant varieties. The photosynthetic stages within the cell are changed to increase hydrogen production through metabolic engineering.

Hydrogen can be produced inthree different ways such as direct biophotolysis, indirect biophotolysis (as shown in Figure 2), and hydrogen production driven by ATP. In direct photolysis biohydrogen is produced by converting water to hydrogen using solar energy through photosynthesis, and is further used as a substrate for anaerobic bacteria during dark fermentation [76]. Such fermentative reactions are typically faster and produce more hydrogen [89].

In indirect photolysis, the microalga produces hydrogen in two steps. In step 1, carbon dioxide is captured through photosynthesis in the presence of solar light. In other terms, microalgae produce oxygen and build up carbon within the cells. In step 2, production of hydrogen takes place through the degradation of the accumulated carbon through anaerobic fermentation which occurs in the absence of oxygen and involves a series of complex biochemical events involving multi-enzyme systems [36,75]. Hydrogenase enzyme plays an important role in this method. As discussed earlier, it is more sensitive to oxygen, so various research is being carried out to develop hydrogenase enzyme which is not sensitive to oxygen. Closed Photobioreactors can be employed for indirect photolysis (Figure 3). The most widely used photobioreactors have atubular design which consists of numerous transparent tubes. The tubes are usually designed to have a diameter less 
than $10 \mathrm{~cm}$ to maximize penetration of solar rays. The microalgal broth is pumped through the tubes, where it is exposed to sunlight for photosynthesis, and then recycled back to a reservoir. Using either a mechanical pump or an airlift pump, the algal biomass is kept from settling by maintaining a very turbulent flow within the reactor [46]. A fraction of the algae is usually collected from the solar tubes. Thus, in this way microalgae can be harvested continuously.

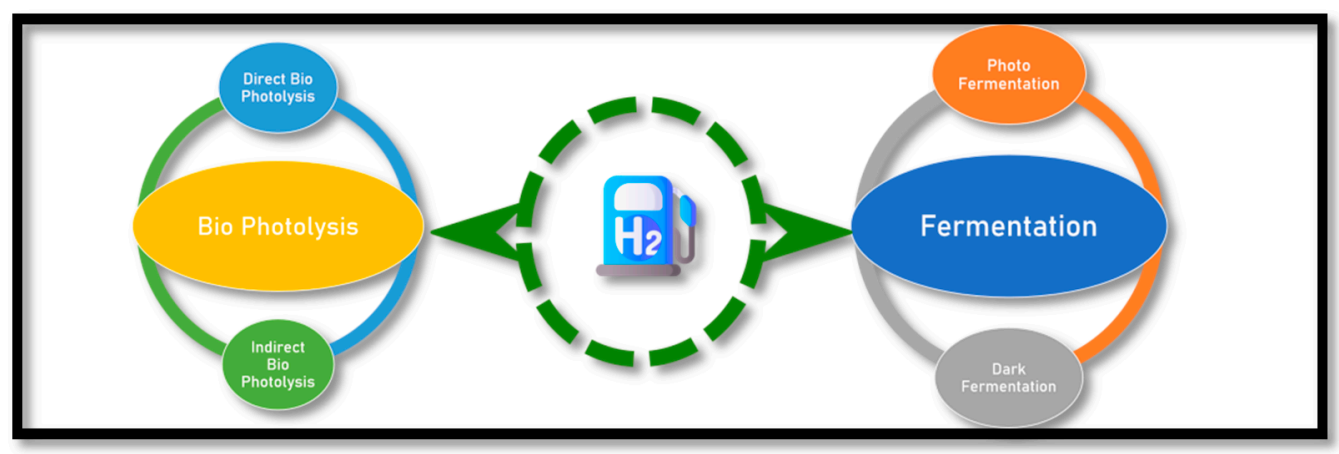

Figure 2. Biohydrogen Production through photolysis and fermentation.

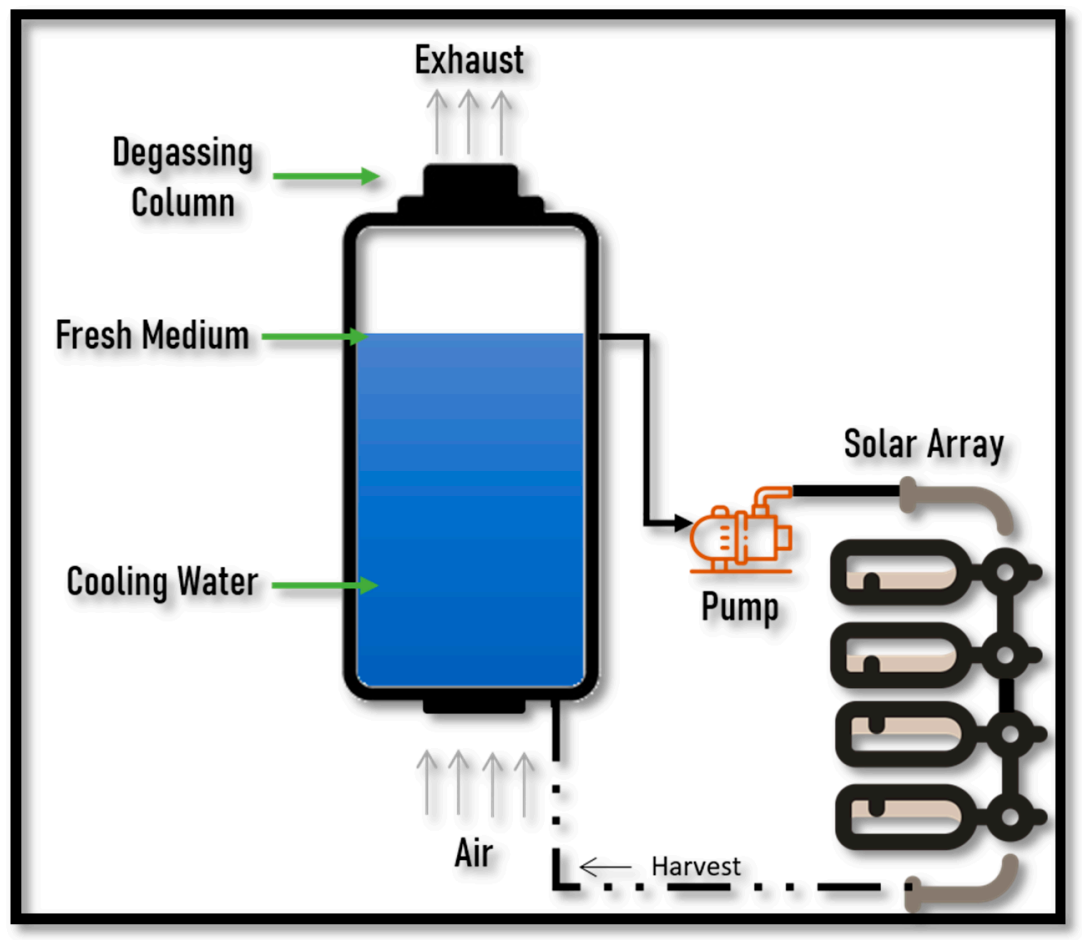

Figure 3. Closed Photobioreactors.

Various literatures have reported that usage of immobilized microalgal cells in the photobioreactors is more advantageous compared to the free cells. Immobilized cells provide increased cell retention time within the bioreactors and enhanced metabolic activity compared to the free cells [90]. Several strategies for improving hydrogen synthesis have been implemented, including varying light intensity, carbon supply, $\mathrm{pH}$, temperature, and sulphur starvation [91,92].

Furthermore, the process's environmental and financial benefits are enhanced by the simultaneous treatment of wastewater and generation of valuable algal biomass [93]. According to Brennan and Owende (2010), in the immediate future, the combination of these processes will be the most reasonable commercial application, and it may be one of the most sustainable methods to generate biofuels [5]. Though the concept of generating 
hydrogen through fermentative metabolism was discovered years ago by Chlamydomonas moewusii [94]; the challenges faced by construction often hinder the application of algal hydrogen generation in a wastewater environment in terms of renewable energy generation and performance characteristics. Moreover, the action of volatile acids such as acetic acid and butyric acid (released during the anaerobic digestion in the wastewater treatment plant) on depletion of oxygen and consequent generation of biohydrogen and its continuity in producing hydrogen has to be studied [95].

\subsection{Bioethanol}

Bioethanol is considered a substitute for conventional petroleum, as they both have the same chemical and physical properties [96-98]. Microalgae biomass, in particular, has lately received a lot of interest as a viable renewable source for the production of biofuels. Thirdgeneration bioethanol made from microalgae biomass could also be an environmentally beneficial fuel. As discussed earlier, microalgae are rich in lipids, enabling it to produce biodiesel. Similarly, some species of microalgae can store large amounts of carbohydrates, such as triacylglycerol and starch, within their cells. These carbohydrates can be used as a carbon source or substrate during fermentation to generate bioethanol $[99,100]$. Proteins can also be accumulated within the cells, along with carbohydrates and lipids under restriction of nitrogen or starvation [101]. Microalgae breakdown the complex nitrogen molecules into protein. Variation in salinity, light intensity, and temperature can also accumulate carbohydrates. Microalgae also lack lignin, and have low hemicellulose levels, making hydrolysis and fermentation yields more efficient [102].

There are three different routes to produce bioethanol from microalgae:(i) The first route is the conventional method, in which the biomass is pretreated, hydrolyzed enzymatically, and fermented using yeast [103]. (ii) The second route operates in the dark condition, and uses metabolic pathways to redirect photosynthesis to create hydrogen, acids, and ethanol [104]. (iii)The third method is to use photofermentation, which is impossible in nature [105]. (iv) The last route necessitates the use of genetic engineering to reroute microalgae's pre-existing metabolic pathways for more subjective and efficient bioethanol synthesis. Bioethanol production from microalgae and cyanobacteria is a viable technical advancement, as they have shown to be more productive than crops such assugarcane and corn. Light is used as an energy source by genetically engineered strains to produce bioethanol from carbon dioxide and water in a single process [106].

\subsubsection{Bioethanol by Hydrolysis and Fermentation}

This route is entirely based on the production of microalgae biomass in photobioreactors, achieved by way of pretreatment steps which involve the hydrolysis of the biomass and breakdown of the cell walls. The biomass is preferably pretreated using enzymes. These treated biomass are further fermented with Sacchromyces cerevisae or bacteria to yield bioethanol.

\subsubsection{Bioethanol by Dark Fermentation}

In this route of dark fermentation, the organic biomass is converted into biohydrogen. Fermentative and hydrolytic microorganisms hydrolyze complex natural polymers into monomers which are, in the end, converted into a combination of low molecular weight organic acids and alcohols such as acetic acid and ethanol.

In the absence of light, certain microalgae and cyanobacteria are capable of expelling ethanol through the cell wall via an intracellular process. Some of the species include Chlamydomonas moewusii, C.vulgaris, C.reinhardtii, Oscillatoria limnetica, O. limosa, Chlorococcum littorale, etc. [102,107]

\subsubsection{Bioethanol by Photofermentation}

Algae can generate bioethanol directly through the photosynthetic process, which is referred to as thephotofermentative or photanol method $[105,107]$. Photofermentation is 
a technology whichis gaining popularity, especially after the announcement of industrial operations that will use modified algae to create bioethanol directly [108]. The photofermentative approach is a natural technique to transform sunlight into fermentation products via a highly efficient metabolic pathway [109].

There has been a recent surge in the number of compounds such as ethanol produced by modified cyanobacteria's photofermentation metabolism. This has been made possible by the information gained from traditional fermentation which is carried out by Escherichia coli and Sacchromyces cerevisiae, which have been genetically modified to generate biofuels such as bioethanol. Algae is a varied group of creatures with a lot of unwrapped genetic potential. Although microalgae are morphologically identical single-celled photosynthetic organisms, the functional genetic diversity is relatively high, as evidenced by the number of unique genes found among distinct species. This genetic diversity is being used to create novel algae strains for the production of biofuels [110].

The use of carbon dioxide and sunlight for carbon uptake and conversion into organic molecules is the most fundamental feature of photosynthesis. Thus, it can be understood that carbon dioxide and light are the two most important variables in increasing production of bioethanol. The photosynthetic efficiency of microalgae ranges from $6-10 \%$ of the incident light, whereas in higher plants, the efficiency is just 1 or 2 percent $[111,112]$. The refinement of geometry, the study of optimal growing circumstances, and the capacity of the photosynthetic machinery to absorb light all contribute to the desired result. In general, microalgae are suitable for the generation of third generation biofuels such as ethanol. Similar to biogas from microalgae, the ethanol production is determined by the pretreatment and the algal strain used [113].

\section{Conclusions}

With the rapid pace of economic development and energy consumption, as well as the limited supply of fossil fuels and the growing need for environmental protection, more attention is being paid to the development of ecologically friendly fuels such as biofuels to resolve the conflict. Microalgae-based biofuels are one of the most promising feedstocks for the next generation of biofuels due to their capacity to produce a high amount of lipids and minimum negative environmental consequence. Algal biofuels can be used in combination with a reduction in carbon dioxide in flue gas and wastewater treatment, as well as the generation of byproducts of high value. The markets for algal biofuel already exist, and are developing, but the markets' growth is constrained due high capital and operational costs, and also due to underdeveloped production technology. Thus, the cost of algal biofuel is increasing. Therefore, more research is to be conducted to improve the technologies used to convert biomass to biofuels, and also produce better harvesting technologies to make algal based biofuels more promising.

Author Contributions: Conceptualization, M.J.; software, M.U.; validation, G.M.; formal analysis, A.S.; investigation, S.P.; writing—original draft preparation, M.J.; and writing—review and editing, R.B.J. All authors have read and agreed to the published version of the manuscript.

Funding: This research received no external funding.

Institutional Review Board Statement: Not applicable.

Informed Consent Statement: Not applicable.

Conflicts of Interest: The authors declare no conflict of interest.

\section{References}

1. Steinman, A.D.; Vymazal, J. Algae and element cycling in wetlands. J. N. Am. Benthol. Soc. 1996, 15, 138-140. [CrossRef]

2. Larkum, A. Photosynthesis in Algae; Kluwer Academic Publisher: Dordrecht, The Netherlands, 2003.

3. Cock, J.M. Introduction to Marine Genomics; Springer: Berlin, Germany, 2010.

4. Lee, R.E. Phycology, 4th ed.; Cambridge University Press: Cambridge, UK, 2008.

5. Brennan, L.; Owende, P. Biofuels from microalgae-A review of technologies for production, processing, and extractions of biofuels and co-products. Renew. Sustain. Energy Rev. 2010, 14, 557-577. [CrossRef] 
6. $\quad$ Feinberg, D.A.; Hill, A.M. Fuel from microalgae lipid products. Algae 1984, 4, 1-17.

7. Packer, M. Algal capture of carbon dioxide; biomass generation as a tool for greenhouse gas mitigation with reference to New Zealand energy strategy and policy. Energy Policy 2009, 37, 3428-3437. [CrossRef]

8. Ren, H.-Y.; Liu, B.-F.; Kong, F.; Zhao, L.; Ma, J.; Ren, N.-Q. Favorable energy conversion efficiency of coupling dark fermentation and microalgae production from food wastes. Energy Convers. Manag. 2018, 166, 156-162. [CrossRef]

9. Wendt, L.M.; Kinchin, C.; Wahlen, B.D.; Davis, R.; Dempster, T.A.; Gerken, H. Assessing the stability and technoeconomic implications for wet storage of harvested microalgae to manage seasonal variability. Biotechnol. Biofuels 2019, 12, 80. [CrossRef] [PubMed]

10. Pritchard, H.N. Microalgae: Biotechnology and microbiology. Q. Rev. Biol. 1995, 70, 350-351. [CrossRef]

11. Christenson, L.; Sims, R. Production and harvesting of microalgae for wastewater treatment, biofuels, and bioproducts. Biotechnol. Adv. 2011, 29, 686-702. [CrossRef] [PubMed]

12. Pittman, J.K.; Dean, A.; Osundeko, O. The potential of sustainable algal biofuel production using wastewater resources. Bioresour. Technol. 2011, 102, 17-25. [CrossRef] [PubMed]

13. de Alva, M.S.; Luna-Pabello, V.M.; Cadena, E.; Ortíz, E. Green microalga Scenedesmusacutus grown on municipal wastewater to couple nutrient removal with lipid accumulation for biodiesel production. Bioresour. Technol. 2013, 146, 744-748. [CrossRef] [PubMed]

14. Prajapati, S.K.; Kaushik, P.; Malik, A.; Vijay, V.K. Phycoremediation coupled production of algal biomass, harvesting and anaerobic digestion: Possibilities and challenges. Biotechnol. Adv. 2013, 31, 1408-1425. [CrossRef] [PubMed]

15. Nayak, M.; Karemore, A.; Sen, R. Performance evaluation of microalgae for concomitant wastewater bioremediation, $\mathrm{CO}_{2}$ biofixation and lipid biosynthesis for biodiesel application. Algal Res. 2016, 16, 216-223. [CrossRef]

16. Prandini, J.M.; da Silva, M.L.B.; Mezzari, M.P.; Pirolli, M.; Michelon, W.; Soares, H.M. Enhancement of nutrient removal from swine wastewater digestate coupled to biogas purification by microalgae Scenedesmus spp. Bioresour. Technol. 2016, 202, 67-75. [CrossRef] [PubMed]

17. Van Wagenen, J.; Pape, M.L.; Angelidaki, I. Characterization of nutrient removal and microalgal biomass production on an industrial waste-stream by application of the deceleration-stat technique. Water Res. 2015, 75, 301-311. [CrossRef] [PubMed]

18. Gao, F.; Li, C.; Yang, Z.-H.; Zeng, G.-M.; Feng, L.; Liu, J.-Z.; Liu, M.; Cai, H.-W. Continuous microalgae cultivation in aquaculture wastewater by a membrane photobioreactor for biomass production and nutrients removal. Ecol. Eng. 2016, 92, 55-61. [CrossRef]

19. Caporgno, M.; Taleb, A.; Olkiewicz, M.; Font, J.; Pruvost, J.; Legrand, J.; Bengoa, C. Microalgae cultivation in urban wastewater: Nutrient removal and biomass production for biodiesel and methane. Algal Res. 2015, 10, 232-239. [CrossRef]

20. Choudhary, P.; Prajapati, S.K.; Malik, A. Screening native microalgal consortia for biomass production and nutrient removal from rural wastewaters for bioenergy applications. Ecol. Eng. 2016, 91, 221-230. [CrossRef]

21. Chinnasamy, S.; Bhatnagar, A.; Hunt, R.W.; Das, K. Microalgae cultivation in a wastewater dominated by carpet mill effluents for biofuel applications. Bioresour. Technol. 2010, 101, 3097-3105. [CrossRef]

22. Wu, L.F.; Chen, P.C.; Huang, A.P.; Lee, C.M. The feasibility of biodiesel production by microalgae using industrial wastewater. Bioresour. Technol. 2012, 113, 14-18. [CrossRef]

23. Wang, L.; Min, M.; Li, Y.; Chen, P.; Chen, Y.; Liu, Y.; Wang, Y.; Ruan, R. Cultivation of green algae Chlorella sp. in different wastewaters from municipal wastewater treatment plant. Appl. Biochem. Biotechnol. 2009, 162, 1174-1186. [CrossRef]

24. Gao, F.; Li, C.; Yang, Z.-H.; Zeng, G.-M.; Mu, J.; Liu, M.; Cui, W. Removal of nutrients, organic matter, and metal from domestic secondary effluent through microalgae cultivation in a membrane photobioreactor. J. Chem. Technol. Biotechnol. 2016, 91, 2713-2719. [CrossRef]

25. Prajapati, S.K.; Choudhary, P.; Malik, A.; Vijay, V.K. Algae mediated treatment and bioenergy generation process for handling liquid and solid waste from dairy cattle farm. Bioresour. Technol. 2014, 167, 260-268. [CrossRef]

26. Mobin, S.; Alam, F. Biofuel production from algae utilizing wastewater. In Proceedings of the 19th Australasian Fluid Mechanics Conference, Melbourne, Australia, 8-11 December 2014.

27. Kiran, B.; Pathak, K.; Kumar, R.; Deshmukh, D. Cultivation of Chlorella sp. IM-01 in municipal wastewater for simultaneous nutrient removal and energy feedstock production. Ecol. Eng. 2014, 73, 326-330. [CrossRef]

28. Escapa, C.; Coimbra, R.; Paniagua, S.; García, A.; Otero, M. Nutrients and pharmaceuticals removal from wastewater by culture and harvesting of Chlorella sorokiniana. Bioresour. Technol. 2015, 185, 276-284. [CrossRef]

29. Khanzada, Z.T. Phosphorus removal from landfill leachate by microalgae. Biotechnol. Rep. 2020, 25, 419. [CrossRef]

30. Kumar, G.; Huy, M.; Bakonyi, P.; Bélafi-Bakó, K.; Kim, S.-H. Evaluation of gradual adaptation of mixed microalgae consortia cultivation using textile wastewater via fed batch operation. Biotechnol. Rep. 2018, 20, 289. [CrossRef]

31. Mar, C.C.; Fan, Y.; Li, F.-L.; Hu, G.-R. Bioremediation of wastewater from edible oil refinery factory using oleaginous microalga Desmodesmus sp. S1. Int. J. Phytoremediat. 2016, 18, 1195-1201. [CrossRef]

32. Choi, H.-J. Dairy wastewater treatment using microalgae for potential biodiesel application. Environ. Eng. Res. 2016, 21, 393-400. [CrossRef]

33. Green, F.B.; Bernstone, L.S.; Lundquist, T.J.; Oswald, W.J. Advanced integrated wastewater pond systems for nitrogen removal. Water Sci. Technol. 1996, 33. [CrossRef]

34. Spolaore, P.; Joannis-Cassan, C.; Duran, E.; Isambert, A. Commercial applications of microalgae. J. Biosci. Bioeng. 2006, 101, 87-96. [CrossRef] 
35. Sialve, B.; Bernet, N.; Bernard, O. Anaerobic digestion of microalgae as a necessary step to make microalgal biodiesel sustainable. Biotechnol. Adv. 2009, 27, 409-416. [CrossRef] [PubMed]

36. Kapdan, I.K.; Kargi, F. Bio-hydrogen production from waste materials. Enzym. Microb. Technol. 2006, 38, 569-582. [CrossRef]

37. Fedorov, A.; Kosourov, S.; Ghirardi, M.L.; Seibert, M. Continuous hydrogen photoproduction by Chlamydomonas reinhardtii: Using a novel two-stage, sulfate-limited chemostat system. Appl. Biochem. Biotechnol. 2005, 121, 0403-0412. [CrossRef]

38. Dexter, J.; Fu, P. Metabolic engineering of cyanobacteria for ethanol production. Energy Environ. Sci. 2009, 2, 857-864. [CrossRef]

39. Choi, S.P.; Nguyen, M.-T.; Sim, S.J. Enzymatic pretreatment of Chlamydomonas reinhardtii biomass for ethanol production. Bioresour. Technol. 2010, 101, 5330-5336. [CrossRef] [PubMed]

40. Xu, H.; Miao, X.; Wu, Q. High quality biodiesel production from a microalga Chlorella protothecoides by heterotrophic growth in fermenters. J. Biotechnol. 2006, 126, 499-507. [CrossRef]

41. Banerjee, A.; Sharma, R.; Chisti, Y.; Banerjee, U.C. Botryococcus braunii: A renewable source of hydrocarbons and other chemicals. Crit. Rev. Biotechnol. 2002, 22, 245-279. [CrossRef] [PubMed]

42. Miao, X.; Wu, Q.; Yang, C. Fast pyrolysis of microalgae to produce renewable fuels. J. Anal. Appl. Pyrolysis 2004, 71, 855-863. [CrossRef]

43. Sawayama, S.; Inoue, S.; Dote, Y.; Yokoyama, S.-Y. $\mathrm{CO}_{2}$ fixation and oil production through microalga. Energy Convers. Manag. 1995, 36, 729-731. [CrossRef]

44. Nagle, N.; Lemke, P. Production of methyl ester fuel from microalgae. Appl. Biochem. Biotechnol. 1990, 24-25, 355-361. [CrossRef]

45. Koberg, M.; Cohen, M.; Ben-Amotz, A.; Gedanken, A. Bio-diesel production directly from the microalgae biomass of Nannochloropsis by microwave and ultrasound radiation. Bioresour. Technol. 2011, 102, 4265-4269. [CrossRef] [PubMed]

46. Chisti, Y. Biodiesel from microalgae. Biotechnol. Adv. 2007, 25, 294-306. [CrossRef] [PubMed]

47. Johnson, M.B.; Wen, Z. Production of biodiesel fuel from the microalga Schizochytrium limacinum by direct transesterification of algal biomass. Energy Fuels 2009, 23, 5179-5183. [CrossRef]

48. Trindade, S.C. Nanotech biofuels and fuel additives. In Biofuel's Engineering Process Technology; IntechOpen: London, UK, 2011.

49. Wahlen, B.; Willis, R.M.; Seefeldt, L. Biodiesel production by simultaneous extraction and conversion of total lipids from microalgae, cyanobacteria, and wild mixed-cultures. Bioresour. Technol. 2011, 102, 2724-2730. [CrossRef]

50. AshokKumar, V.; Agila, E.; Sivakumar, P.; Salam, Z.; Rengasamy, R.; Ani, F.N. Optimization and characterization of biodiesel production from microalgae Botryococcus grown at semi-continuous system. Energy Convers. Manag. 2014, 88, 936-946. [CrossRef]

51. Lewis, T.; Nichols, P.D.; McMeekin, T.A. Evaluation of extraction methods for recovery of fatty acids from lipid-producing microheterotrophs. J. Microbiol. Methods 2000, 43, 107-116. [CrossRef]

52. Danielo, O. An Algae-Based Fuel; Biofuture: Venelles, France, 2005.

53. Metzger, P.; Largeau, C. Botryococcus braunii: A rich source for hydrocarbons and related ether lipids. Appl. Microbiol. Biotechnol. 2004, 66, 486-496. [CrossRef]

54. Knothe, G. The Biodiesel Handbook; AOCS Press: Urbana, IL, USA, 2005.

55. Kumar, M.; Sharma, M.P. Selection of potential oils for biodiesel production. Renew. Sustain. Energy Rev. 2016, 56, 1129-1138. [CrossRef]

56. Ribeiro, N.M.; Pinto, A.C.; Quintella, C.; da Rocha, G.O.; Teixeira, L.; Guarieiro, L.L.N.; Rangel, M.D.C.; Veloso, M.C.C.; Rezende, M.J.C.; da Cruz, R.S.; et al. The role of additives for diesel and diesel blended (ethanol or biodiesel) fuels: A review. Energy Fuels 2007, 21, 2433-2445. [CrossRef]

57. Bhale, P.V.; Deshpande, N.; Thombre, S.B. Improving the low temperature properties of biodiesel fuel. Renew. Energy 2009, 34, 794-800. [CrossRef]

58. Zabed, H.M.; Boyce, A.N.; Sahu, J.N.; Faruq, G. Evaluation of the quality of dried distiller's grains with solubles for normal and high sugary corn genotypes during dry-grind ethanol production. J. Clean. Prod. 2017, 142, 4282-4293. [CrossRef]

59. Ayala-Parra, P.; Liu, Y.; Field, J.; Sierra-Alvarez, R. Nutrient recovery and biogas generation from the anaerobic digestion of waste biomass from algal biofuel production. Renew. Energy 2017, 108, 410-416. [CrossRef]

60. Zamalloa, C.; Boon, N.; Verstraete, W. Anaerobic digestibility of Scenedesmus obliquus and Phaeodactylum tricornutum under mesophilic and thermophilic conditions. Appl. Energy 2012, 92, 733-738. [CrossRef]

61. Saratale, R.G.; Kumar, G.; Banu, R.; Xia, A.; Periyasamy, S.; Saratale, G.D. A critical review on anaerobic digestion of microalgae and macroalgae and co-digestion of biomass for enhanced methane generation. Bioresour. Technol. 2018, 262, 319-332. [CrossRef]

62. Ward, A.; Lewis, D.; Green, F. Anaerobic digestion of algae biomass: A review. Algal Res. 2014, 5, 204-214. [CrossRef]

63. Park, J.; Craggs, R.; Shilton, A. Wastewater treatment high rate algal ponds for biofuel production. Bioresour. Technol. 2011, 102, 35-42. [CrossRef] [PubMed]

64. Sivakumar, G.; Xu, J.; Thompson, R.W.; Yang, Y.; Randol-Smith, P.; Weathers, P.J. Integrated green algal technology for bioremediation and biofuel. Bioresour. Technol. 2012, 107, 1-9. [CrossRef] [PubMed]

65. Xu, J.; Zhao, Y.; Zhao, G.; Zhang, H. Nutrient removal and biogas upgrading by integrating freshwater algae cultivation with piggery anaerobic digestate liquid treatment. Appl. Microbiol. Biotechnol. 2015, 99, 6493-6501. [CrossRef]

66. Ehimen, E.; Sun, Z.; Carrington, C.; Birch, E.; Eaton-Rye, J. Anaerobic digestion of microalgae residues resulting from the biodiesel production process. Appl. Energy 2011, 88, 3454-3463. [CrossRef]

67. Sforza, E.; Barbera, E.; Girotto, F.; Cossu, R.; Bertucco, A. Anaerobic digestion of lipid-extracted microalgae: Enhancing nutrient recovery towards a closed loop recycling. Biochem. Eng. J. 2017, 121, 139-146. [CrossRef] 
68. Gonzalez, L.M.; Correa, D.F.; Ryan, S.; Jensen, P.D.; Pratt, S.; Schenk, P.M. Integrated biodiesel and biogas production from microalgae: Towards a sustainable closed loop through nutrient recycling. Renew. Sustain. Energy Rev. 2018, 82, 1137-1148. [CrossRef]

69. Golueke, C.G.; Oswald, W.J.; Gotaas, H.B. Anaerobic digestion of algae. Appl. Microbiol. 1957, 5, 47-55. [CrossRef]

70. Klassen, V.; Blifernez-Klassen, O.; Wobbe, L.; Schlüter, A.; Kruse, O.; Mussgnug, J.H. Efficiency and biotechnological aspects of biogas production from microalgal substrates. J. Biotechnol. 2016, 234, 7-26. [CrossRef]

71. Klassen, V.; Blifernez-Klassen, O.; Hoekzema, Y.; Mussgnug, J.H.; Kruse, O. A novel one-stage cultivation/fermentation strategy for improved biogas production with microalgal biomass. J. Biotechnol. 2015, 215, 44-51. [CrossRef] [PubMed]

72. Xu, Y.; Huang, Y.; Wu, B.; Zhang, X.; Zhang, S. Biogas upgrading technologies: Energetic analysis and environmental impact assessment. Chin. J. Chem. Eng. 2015, 23, 247-254. [CrossRef]

73. Krischan, J.; Makaruk, A.; Harasek, M. Design and scale-up of an oxidative scrubbing process for the selective removal of hydrogen sulfide from biogas. J. Hazard. Mater. 2012, 215-216, 49-56. [CrossRef] [PubMed]

74. Wang, J.; Wan, W. Factors influencing fermentative hydrogen production: A review. Int. J. Hydrogen Energy 2009, 34, 799-811. [CrossRef]

75. Argun, H.; Kargi, F.; Kapdan, I.K.; Oztekin, R. Biohydrogen production by dark fermentation of wheat powder solution: Effects of $\mathrm{C} / \mathrm{N}$ and $\mathrm{C} / \mathrm{P}$ ratio on hydrogen yield and formation rate. Int. J. Hydrogen Energy 2008, 33, 1813-1819. [CrossRef]

76. Ferreira, A.F.; Marques, A.C.; Batista, A.P.; Marques, P.A.; Gouveia, L.; Silva, C. Biological hydrogen production by Anabaena sp.-Yield, energy and $\mathrm{CO}_{2}$ analysis including fermentative biomass recovery. Int. J. Hydrogen Energy 2012, 37, 179-190. [CrossRef]

77. Ruiz-Marin, A.; Canedo-López, Y.; Chávez-Fuentes, P. Biohydrogen production by Chlorella vulgaris and Scenedesmus obliquus immobilized cultivated in artificial wastewater under different light quality. AMB Express 2020, 10, 1-7. [CrossRef] [PubMed]

78. Nobre, B.; Villalobos, F.; Barragán-Huerta, B.E.; Oliveira, A.; Batista, A.P.; Marques, P.; Mendes, R.; Sovova, H.; Palavra, A.; Gouveia, L. A biorefinery from Nannochloropsis sp. microalga-Extraction of oils and pigments. Production of biohydrogen from the leftover biomass. Bioresour. Technol. 2013, 135, 128-136. [CrossRef] [PubMed]

79. Batyrova, K.; Hallenbeck, P.C. Hydrogen production by a Chlamydomonas reinhardtii strain with inducible expression of photosystem II. Int. J. Mol. Sci. 2017, 18, 647. [CrossRef] [PubMed]

80. Juantorena, A.; Sebastian, P.; Santoyo, E.; Gamboa, S.; Lastres, O.; Sánchez-Escamilla, D.; Bustos, A.; Eapen, D. Hydrogen production employing Spirulina maxima 2342: A chemical analysis. Int. J. Hydrogen Energy 2007, 32, 3133-3136. [CrossRef]

81. Batista, A.P.; Moura, P.; Marques, P.A.; Ortigueira, J.; Alves, L.; Gouveia, L. Scenedesmus obliquus as feedstock for biohydrogen production by Enterobacter aerogenes and Clostridium butyricum. Fuel 2014, 117, 537-543. [CrossRef]

82. Wieczorek, N.; Kucuker, M.A.; Kuchta, K. Fermentative hydrogen and methane production from microalgal biomass (Chlorella vulgaris) in a two-stage combined process. Appl. Energy 2014, 132, 108-117. [CrossRef]

83. Yang, Z.; Guo, R.; Xu, X.; Fan, X.; Li, X. Enhanced hydrogen production from lipid-extracted microalgal biomass residues through pretreatment. Int. J. Hydrogen Energy 2010, 35, 9618-9623. [CrossRef]

84. Vijayaraghavan, K.; Karthik, R.; Nal, S.K. Hydrogen generation from algae: A review. J. Plant Sci. 2009, 5, 1-19. [CrossRef]

85. Rupprecht, J.; Hankamer, B.; Mussgnug, J.H.; Ananyev, G.; Dismukes, C.; Kruse, O. Perspectives and advances of biological $\mathrm{H}_{2}$ production in microorganisms. Appl. Microbiol. Biotechnol. 2006, 72, 442-449. [CrossRef]

86. Kosourov, S.; Patrusheva, E.; Ghirardi, M.L.; Seibert, M.; Tsygankov, A. A comparison of hydrogen photoproduction by sulfurdeprived Chlamydomonas reinhardtii under different growth conditions. J. Biotechnol. 2007, 128, 776-787. [CrossRef]

87. Gaffron, H.; Rubin, J. Fermentative and photochemical production of hydrogen in algae. J. Gen. Physiol. 1942, 26, 219-240. [CrossRef] [PubMed]

88. Kessler, E. Hydrogenase, photoreduction, and anaerobic growth. In Algal Physiology and Biochemistry; University of California Press: Berkeley, CA, USA, 1974.

89. Hallenbeck, P. Fundamentals of the fermentative production of hydrogen. Water Sci. Technol. 2005, 52, 21-29. [CrossRef] [PubMed]

90. Tam, N.; Wong, Y. Effect of immobilized microalgal bead concentrations on wastewater nutrient removal. Environ. Pollut. 2000, 107, 145-151. [CrossRef]

91. Azwar, M.; Hussain, M.A.; Abdul-Wahab, A. Development of biohydrogen production by photobiological, fermentation and electrochemical processes: A review. Renew. Sustain. Energy Rev. 2014, 31, 158-173. [CrossRef]

92. Rashid, N.; Lee, K.; Han, J.-I.; Gross, M. Hydrogen production by immobilized Chlorella vulgaris: Optimizing pH, carbon source and light. Bioprocess Biosyst. Eng. 2012, 36, 867-872. [CrossRef]

93. Razzak, S.; Hossain, M.M.; Lucky, R.A.; Bassi, A.S.; de Lasa, H. Integrated $\mathrm{CO}_{2}$ capture, wastewater treatment and biofuel production by microalgae culturing-A review. Renew. Sustain. Energy Rev. 2013, 27, 622-653. [CrossRef]

94. Klein, U.; Betz, A. Fermentative metabolism of hydrogen-evolving Chlamydomonas moewusii. Plant Physiol. 1978, 61, 953-956. [CrossRef] [PubMed]

95. Jurado-Oller, J.L.; Dubini, A.; Galván, A.; Fernández, E.; González-Ballester, D. Low oxygen levels contribute to improve photohydrogen production in mixotrophic non-stressed Chlamydomonas cultures. Biotechnol. Biofuels 2015, 8, 1-14. [CrossRef] [PubMed]

96. Dale, B.E. Thinking clearly about biofuels: Ending the irrelevant 'net energy' debate and developing better performance metrics for alternative fuels. Biofuels Bioprod. Biorefin. 2007, 1, 14-17. [CrossRef] 
97. Demirbaş, A. Conversion of biomass using glycerin to liquid fuel for blending gasoline as alternative engine fuel. Energy Convers. Manag. 2000, 41, 1741-1748. [CrossRef]

98. Naik, S.; Goud, V.V.; Rout, P.K.; Dalai, A.K. Production of first and second generation biofuels: A comprehensive review. Renew. Sustain. Energy Rev. 2010, 14, 578-597. [CrossRef]

99. Harun, R.; Singh, M.; Forde, G.M.; Danquah, M.K. Bioprocess engineering of microalgae to produce a variety of consumer products. Renew. Sustain. Energy Rev. 2010, 14, 1037-1047. [CrossRef]

100. Radakovits, R.; Jinkerson, R.; Darzins, A.; Posewitz, M.C. Genetic engineering of algae for enhanced biofuel production. Eukaryot. Cell 2010, 9, 486-501. [CrossRef]

101. González-Fernández, C.; Ballesteros, M. Linking microalgae and cyanobacteria culture conditions and key-enzymes for carbohydrate accumulation. Biotechnol. Adv. 2012, 30, 1655-1661. [CrossRef]

102. Ueno, Y.; Kurano, N.; Miyachi, S. Ethanol production by dark fermentation in the marine green alga, Chlorococcum littorale. J. Ferment. Bioeng. 1998, 86, 38-43. [CrossRef]

103. Hernández, D.; Riaño, B.; Coca, M.; González, M.C.G. Saccharification of carbohydrates in microalgal biomass by physical, chemical and enzymatic pre-treatments as a previous step for bioethanol production. Chem. Eng. J. 2015, 262, 939-945. [CrossRef]

104. Magneschi, L.; Catalanotti, C.; Subramanian, V.; Dubini, A.; Yang, W.; Mus, F.; Posewitz, M.C.; Seibert, M.; Perata, P.; Grossman, A.R. A mutant in the ADH1 gene of Chlamydomonas reinhardtii elicits metabolic restructuring during anaerobiosis. Plant Physiol. 2012, 158, 1293-1305. [CrossRef]

105. Dexter, J.; Armshaw, P.; Sheahan, C.; Pembroke, J.T. The state of autotrophic ethanol production in cyanobacteria. J. Appl. Microbiol. 2015, 119, 11-24. [CrossRef] [PubMed]

106. Saad, M.G.; Dosoky, N.S.; Zoromba, M.S.; Shafik, H.M. Algal Biofuels: Current Status and Key Challenges. Energies 2019, 12, 1920. [CrossRef]

107. Deng, M.-D.; Coleman, J.R. Ethanol synthesis by genetic engineering in cyanobacteria. Appl. Environ. Microbiol. 1999, 65, 523-528. [CrossRef]

108. Piven, I.; Friedrich, A.; Dühring, U.; Uliczka, F.; Baier, K.; Inaba, M. Cyanobacterium sp. for Production of Compounds. U.S. Patent US20140178958A1, 26 June 2012.

109. Hellingwerf, K.; De Mattos, M.T. Alternative routes to biofuels: Light-driven biofuel formation from $\mathrm{CO}_{2}$ and water based on the 'photanol' approach. J. Biotechnol. 2009, 142, 87-90. [CrossRef]

110. Gimpel, J.; Specht, E.A.; Georgianna, D.R.; Mayfield, S.P. Advances in microalgae engineering and synthetic biology applications for biofuel production. Curr. Opin. Chem. Biol. 2013, 17, 489-495. [CrossRef]

111. Sforza, E.; Gris, B.; De Farias Silva, C.E.; Morosinotto, T.; Bertucco, A. Effects of light on cultivation of scenedesmus obliquus in batch and continuous flat plate photobioreactor. Chem. Eng. Trans. 2014, 38, 211-216. [CrossRef]

112. Peccia, J.; Haznedaroglu, B.Z.; Gutierrez, J.; Zimmerman, J.B. Nitrogen supply is an important driver of sustainable microalgae biofuel production. Trends Biotechnol. 2013, 31, 134-138. [CrossRef] [PubMed]

113. Kuhad, R.C.; Gupta, R.; Khasa, Y.P.; Singh, A.; Zhang, Y.-H.P. Bioethanol production from pentose sugars: Current status and future prospects. Renew. Sustain. Energy Rev. 2011, 15, 4950-4962. [CrossRef] 